Julia K. Kochb, *, Katharina Kupkea, b

\title{
Life-course reconstruction for mobile individuals in an Early Bronze Age society in Central Europe: Concept of the project and first results for the cemetery of Singen (Germany)
}

\author{
* Corresponding author: jkkoch@uni-leipzig.de \\ a MPI of Evolutionary Anthropology. Dept. of Human Ori- \\ gin, Leipzig, Germany \\ b Department of History - Chair of Pre- and Protohistory, \\ University Leipzig, Germany
}

\begin{abstract}
The German Ministry of Education and Research sponsored project "Life course reconstruction of mobile individuals in sedentary societies", run by the Chair of Proto- and Prehistory, University of Leipzig, and by the Dept. of Human Evolution, Max Planck Institute of Evolutionary Anthropology (MPIEVA), investigates mobility as part of the human life course in cultural groups during the beginnings of the Bronze and Iron Ages in Central Europe. Starting with the basic question 'What role do individual mobility and the integration of foreign persons play in the development of prehistoric sedentary societies?' the archaeological subproject investigates the links
\end{abstract}

\begin{abstract}
between the mobility of individuals and gender roles and between the former and the transfer of technologies in prehistoric sedentary societies. The results of isotope analyses now offer the chance to compare data on geographical provenance with cultural data. So the research of the MPI-EVA's component of the project focuses on the analysis of five stable isotopes - strontium, oxygen, sulphur, carbon, and nitrogen - to reconstruct dietary habits and provenance in different life stages. The project focuses on the Early Bronze Age cemetery of Singen (district of Constance) and the Early Iron Age burial mound the Magdalenenberg near Villingen-Schwenningen (Schwarzwald-Baar district), both in Baden-Württemberg, Germany.
\end{abstract}

\section{Keywords}

Early Bronze Age, Central Europe, Integration, Mobility, Diet, Multiple Isotope Analysis, Social Analysis

\section{Introduction}

The project "Life course reconstruction of mobile individuals in sedentary societies", run by the Chair of Proto- and Prehistory, University of Leipzig, and by the Dept. of Human Evolution, Max Planck Institute of Evolutionary Anthropology, investigates mobility as part of the human life course in cultural groups during the beginning of both metal periods in Central Europe. Thus unlike other archaeological projects involving isotope analyses, it does not address the question of mass-migration, but examines instead the mobility of individuals and its significance with respect to cultural developments, especially innovations.

\section{Definition of life course}

Before we present the main strands of the project, we will provide a definition of the term 'life course', because this key concept - adopted from Gender Archaeology (Sofaer Derevenski, I997; Gilchrist, 2000) - together with the term "lifecycles" forms a complement to "life history", which has often been used in recent anthropological studies (Koch, 20I0).

Life course is understood by R. Gilchrist (2000) as the progression through which members of social groups pass during their physical lifecycle, embedded in their own cultural context with all of the continuities and discontinuities associated therewith. An individual's life course is influenced both by cultural categories, which are mutable, such as gender, status, cultural origin or diet, and by biological 


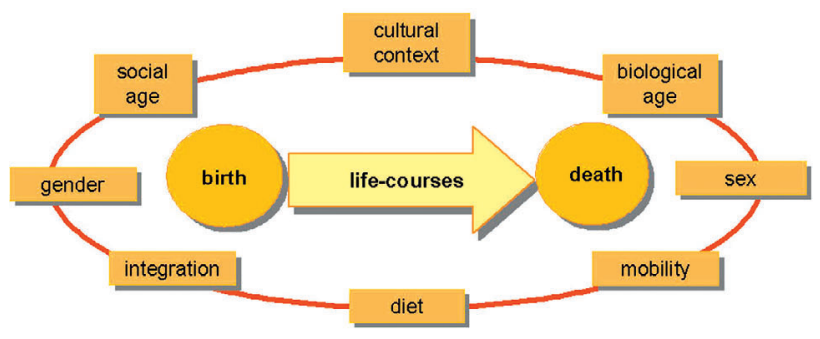

Fig. 1 Model of the influences on a prehistoric life course

ones, such as sex, biological age or natural environment (Fig. I). Hence a life course is perceived as 'a series of stages, hierarchical grades or physical thresholds, that may be marked by public or private rites of passage. Alternatively, the passage of an individual life may be linked with daily, seasonal or annual cycles, with natural and personal time-scales fully integrating the lifecycle of the wider social community' (Gilchrist, 2000). In addition, the life course concept implies that no single social group should be studied in isolation, but that an examination should encompass all groups in order to study interactions, boundaries and convergences, as well as to identify differences and similarities among gender and age groups (cf. Gilchrist I999).

The term 'life history' is more commonly used in physical anthropology, but in contrast to 'life cycle', it entails an individual and very personal level which can be gleaned through a combination of human being and object (Gilchrist, 2000). In archaeology the temptation to reconstruct the life history of a particular person (i.e. grave owner) is frequently very great; however in our opinion an individualspecific approach approximation must be accompanied by careful analysis that takes into account all critical objections regarding sources. In prehistoric anthropology, focusing on biographical aspects on the basis of individual skeletons would seem the simpler approach (Alt, 2004).

\section{Project organisation and research questions}

The project comprises two component projects: one at the MPI-EVA, one at Leipzig University (Fig. 2). On the side of archaeometric science, the project team, coordinated by Michael Richards, is carrying out a multiple-isotope analysis (strontium, oxygen, sulphur, carbon and nitrogen) to obtain information about the provenance and diet of the human individuals. The second team, supervised by Sabine Rieckhoff, is focusing on a newly developed integration analysis, which aims to determine the degree of cultural integration of individuals. Finally, a synthesis brings together the results for the two, chronologically widely separated, case studies to tease out the structural relationships between gender, social age, status, mobility and diet, while also considering possible changes during different life courses. The aim is to outline new, well-substantiated models for the interrelationship between mobility and cultural development based on a diachronic comparison.

Beginning with the basic question 'What role do individual mobility and the integration of foreign persons play in the development of prehistoric sedentary societies?' the archaeological project cluster investigates the links between the mobility of individuals and gender roles and between the former and the transfer of technologies in prehistoric sedentary societies. The starting point is the hypothesis that individuals, depending on their social status as defined by age and gender, will, firstly, show differences in their mobility pattern and, secondly, be able to implement different models of integration. Hence the phenomenon of the 'mobile person' is not being investigated by concentrating on just one age or gender 
Fig. 2 | Organisation of the project "Life course reconstruction of mobile individuals in sedentary societies"

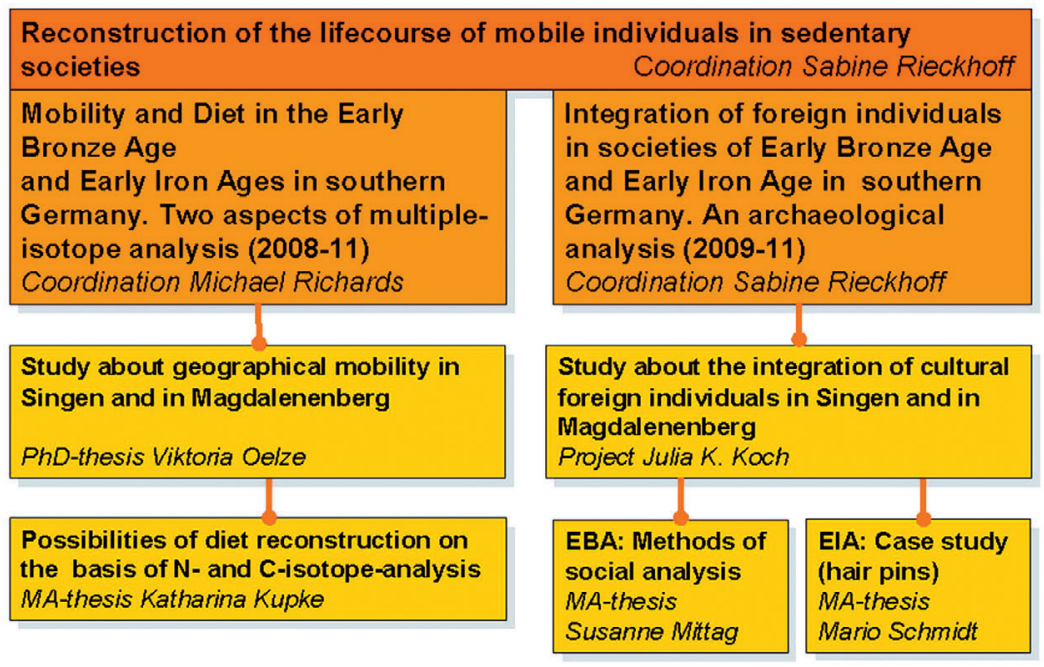

group, or even from a 'genderless' perspective, but instead it is seen as integral to the entirety of the existing social structures, which influenced individual biographies in their turn.

The methodological question concerns ways of identifying mobile individuals. In the past, archaeologists have happily assumed that the presence of "foreign" artefacts or burial rites represents evidence of the presence of actual foreigners, even when there was no reason to suppose an intimate link between the objects and the individuals buried. Another problematic aspect is that it is possible for one-time "foreigners" to be so well integrated that they are no longer visible culturally, while people who never actually left their societies might be represented as "mobile individuals" due to their association with imported objects. Isotope analyses now offer researchers an opportunity to compare data on geographical provenance with cultural data. The rate of integration can, but does not have to be conditioned by any actual spatial movement. Isotopic analysis of diet takes up an intermediary position here. It is necessary to provide background data to aid in interpretation the isotopes shedding light on individual movements and also provides additional evidence relating to the rate of integration, since diet is culturally dependent.

Research in the MPI component project focuses on the analysis of five stable isotopes - strontium, oxygen, sulphur, carbon, and nitrogen - to allow the reconstruction of dietary habits and provenance in different life stages. The set of samples encompasses all available skeletons and some animal bones from both sites. By examining the carbon, nitrogen and sulphur stable isotope ratios in combination, we are able to detect the exploitation of terrestrial, marine and freshwater resources. Due to its potential for ascertaining differences or similarities in diet that are related to age, sex and gender, this investigation into diet using carbon and nitrogen isotope values represents one piece of the puzzle that is lifecourse reconstruction. It also, however, serves as a control element in respect of the other isotope ratios, particularly in cases of extreme values. To shed light on the question of human mobility, isotope ratios of strontium and oxygen in human tooth enamel and sulphur isotopes in bone collagen will be analysed. The signature of strontium isotopes in the human enamel should reflect the geological origin of food and drinking water consumed during enamel formation in early childhood; oxygen isotopes in the enamel should correspond to those of the local drinking water. Sulphur isotopes are measured in bone collagen, which reflects the geological origin of food consumed in the last decade of life (Nehlich and Richards, 2009); this signature can hence also be used to distinguish between local and nonlocal indi- 
viduals (Richards et al., 200I; Buchardt et al., 2007; Bol et al., 2007; Vika, 2009). By combining both methods we can reconstruct early childhood (strontium, oxygen) and adult provenance (sulphur).

The project focuses on the Early Bronze Age and the Early Iron Age in south-western Germany, as each of these represents an important horizon of innovation. The introduction of, respectively, tin bronze and iron processing presupposes a transfer of technologies with far-reaching consequences, but evidence for the movement of larger groups is lacking. Therefore, this project envisages an increase in the mobility of single individuals and very small groups. The Early Bronze Age cemetery of Singen (district of Constance) and the Early Iron Age burial mound known as the Magdalenenberg near VillingenSchwenningen (Schwarzwald-Baar district), both in Baden-Württemberg, Germany, form the core of the two case studies, each of which is being investigated separately.

The decisive factors in the choice of these two sites were the conditions they provide: substantial find assemblages, comprehensive and reliable publications, including anthropological data and specialist reports, as well as scientific dates. In addition, certain elements of burial treatment can be shown to vary with the social categories of age and gender in both communities. That makes correlations between patterns of social behaviour, such as mobility and integration, and variables of age and gender very likely for both communities as well. Another reason for the selection was the existence of published suggestions of mobility in relation to certain grave complexes, which we set out to test.

As our project is still in progress, the focus of the present article is on the conceptual aspects of the project and on first results from the MA thesis concerned with the diet of the chosen populations. The case study of Singen will be used to illustrate the working methods.

\section{The sites}

The 96 graves in the cemetery of Singen in the Hegau region are divided into five groups (Fig. 3) and have been dated to the Early Bronze Age, i.e. Reinecke Ai or, in absolute dates, the $22^{\text {nd }}-20^{\text {th }}$ century cal BC (Krause, I988). A further grave, Singen Grave 7I, has so far been assigned to the Early Bronze Age

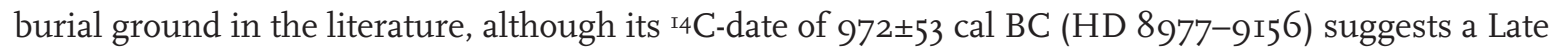
Bronze Age date and supports its allocation to the corresponding cremation cemetery in the same area (cf. Krause, I988; Brestrich, I998). The date was calibrated using CalPal (online version). In spite of the generally poor conditions for bone preservation in the Hegau region, 36 graves yielded bone fragments and teeth, constituting one of the largest assemblages for the North Alpine Early Bronze Age. Rüdiger Krause (I988), the first to work on the Singen material, interpreted the site as the burial place of a 'socially and politically dominant group' within the northern Alpine metallurgy network (Krause, I988; 2002; 2009). The finds themselves confirm contacts with the Atlantic Early Bronze Age and as far as Hungary to the east. On the basis of foreign elements in the funerary rite, Krause (I988) interpreted the isolated Group IIb, consisting of six graves, as the burials of immigrants.

For the sake of completeness, the second site should be mentioned briefly: the 139 individuals from I27 graves within the Magdalenenberg near Villingen-Schwenningen at the eastern edge of the Black Forest have been dendro-dated to the beginning of the late Hallstatt period (ca. 6I6-570/560 BC) (Spindler I97I-80; I999; 2004). More skeletal material is preserved here, albeit in a fragile state. A total of 99 individuals are represented (Gallay, I977; Wahl and Zäuner, 20I0). Some grave good inventories contain stone tools for metalworking, suggesting that several persons were familiar with the newly introduced iron metallurgy (Spindler, I999). In spite of this connection with a transfer of technology, the 


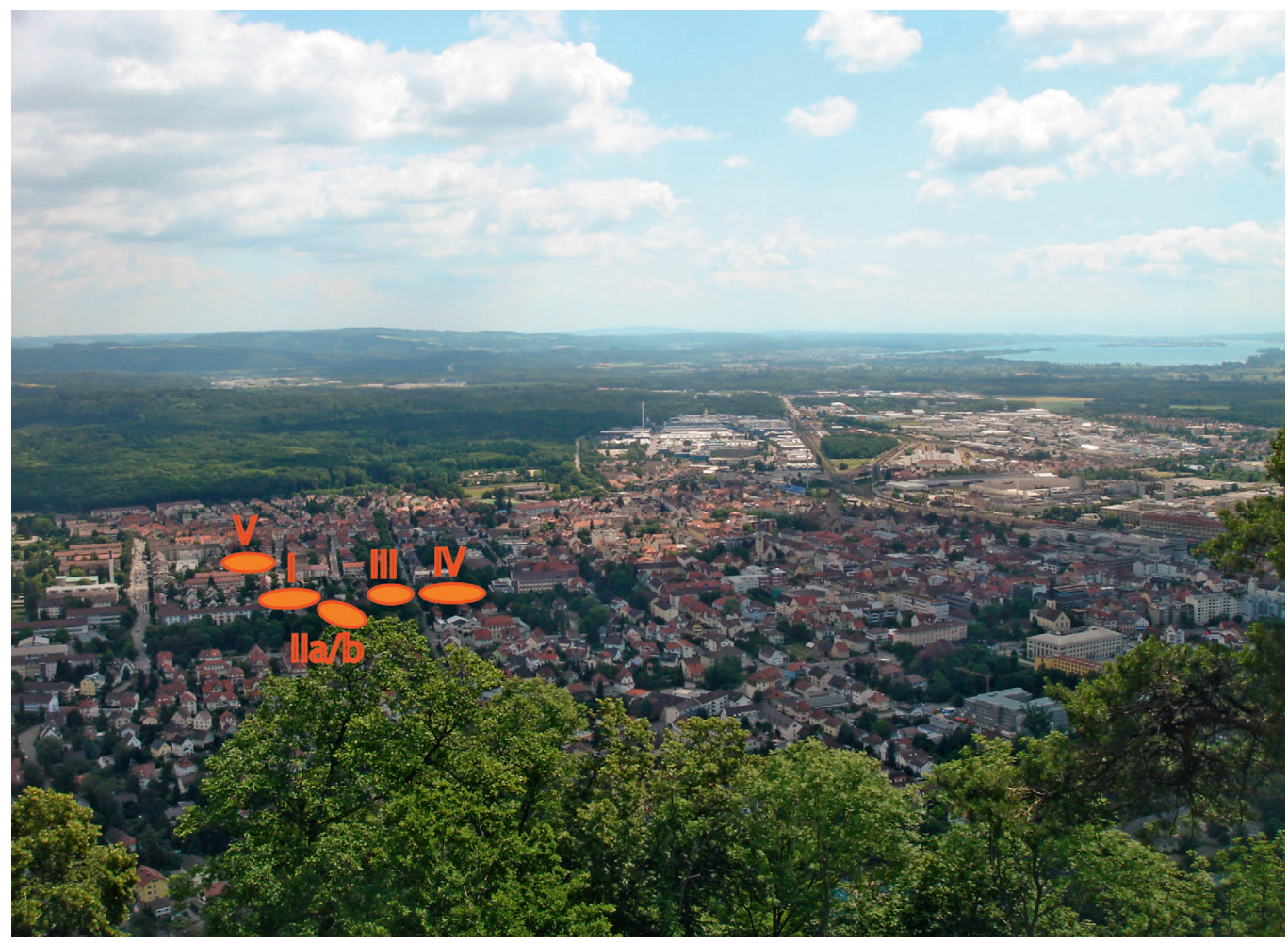

Fig. 3 | Singen, district of Constance, Baden-Württemberg, Germany. View to the west from the volcanic mountain Hohentwiel above the city of Singen, with Lake Constance in the background. The site of the five EBA grave groups is marked in red (Photo: J. Koch)

excavator, Konrad Spindler (I999), was of the opinion that a local population was buried in the Magdalenenberg, given the homogenous grave good inventory largely typical for Ha DI in south-western Germany. However, individual imported pieces, such as elements of southern Alpine dress (cf. Schmid-Sikimić, 2002), as well as exotic raw materials such as coral and amber, reinforce the idea that this burial site, too, contains individuals integrated into interregional networks.

Thus both sites provide an excellent basis for assessing the hypothesis of gender-differentiated mobility and integration behaviours using diachronic comparison of two chronological phases, both characterised by the introduction of new metalworking technologies, as well as for the reconstruction of the social repercussions of cultural changes potentially caused by 'foreigners'.

\section{Scientific project: Early Bronze Age diet}

Though analyses on the strontium, oxygen and sulphur isotopes are not yet complete (Oelze et al., submitted manuscript), the results of the carbon and nitrogen analyses can be briefly summarised here (Kupke, 20II). The question of diet is an important aspect for the reconstruction of prehistoric life courses. As the choice of foods is determined not only culturally, but also depends on the immediate environment, different connections within the framework of prehistoric life courses can be investigated on the basis of this reconstruction. 


\section{Materials and methods}

Bone samples were taken from 33 individuals of the 97 Bronze Age inhumations at Singen (Fig. 4). All age groups, from infants to adults over 60 years of age, are represented. Of these, 13 individuals have been identified anthropologically as male, six as female and I4 as indeterminate.

With the exception of one herbivore (Grave 80), no animal bone from Singen or its immediate surroundings was available to be sampled. Instead, isotope data for herbivores from different chronological periods - the Neolithic cemeteries of Trebur, district of Groß-Gerau (Dürrwächter et al. 2003), and Pestenacker, district of Landsberg am Lech (Asam et al. 2006); the Urnfield cemetery at Neckarsulm, district of Heilbronn (Nehlich and Wahl, 2oIo); and the Magdalenenberg, Schwarzwald-Baar district (Kupke, 20II) were collated to obtain a rough indication of characteristic dietary values for herbivores. Collagen extraction was carried out on the basis of the method developed by Longin (I97I), as modified by Brown et al. (I988) and further developed by Richards and Hedges (I999) and Müldner and Richards (2005). Samples were measured in a Delta XP mass spectrometer with Flash EA 2Iı2 (Thermo-Finnigan ${ }^{\circledR}$ ). The analytical measurement error of duplicate collagen samples was below $\pm 0.1 \%$. All statistical analyses of carbon and nitrogen isotope data were undertaken with the statistics program R ( $R$ Development Core Team 2009).

\section{Results}

The carbon and nitrogen isotopes were subjected to the usual quality criteria (Ambrose, I990; DeNiro, I985; van Klinken, I999). Although a collagen yield of less than one percent is regarded as problematic, samples were not discarded as long as they passed other quality controls, since due to the ultra-filtration used, there was a greater loss of degraded collagen (Müldner and Richards, 2005). Apart from two samples which did not contain sufficient collagen, it was possible to extract collagen from all samples, and carbon and nitrogen isotope data could be obtained. Six other samples were also rejected as they did not satisfy the quality criteria. The mean of all usable isotope data from the Singen cemetery is $-20.4 \pm$ $0.3 \%$ for the $\delta^{13} \mathrm{C}$ values, with a maximum of $-\mathrm{I} 9.6 \%$ and a minimum of $-2 \mathrm{I} .2 \%$. The $\delta^{15} \mathrm{~N}$ values scatter between $10.5 \%$ and $7.9 \%$, with a mean of $9.6 \pm 0.6 \%$.

\section{Discussion of isotope data}

The data for animals provide the basis for the interpretation of human carbon and nitrogen isotope data. Herbivore isotope values allow the botanical and regional climatic conditions of the time period in question to be determined and subsequently compared with human diet (Jay and Richards, 2006). With the exception of the possible herbivore from the Singen cemetery, no other animals were available, and hence the herbivore baseline, which forms the basis for the interpretation of the human isotope data, is missing.

To allow us to interpret the carbon and nitrogen isotope data for the humans from the Singen cemetery despite this absence, the herbivores from the sites listed in the section on materials and methods were used to gain an approximate idea of the characteristic dietary values for herbivores.

The increase of the $\delta^{{ }^{13}} \mathrm{C}$ mean values of the herbivores and humans measures about $\mathrm{I}-2 \%$; the increase in the $\delta^{15} \mathrm{~N}$ mean values between herbivores and humans was 3-4\%o, thus corresponding to one trophic level (DeNiro and Epstein, I978, I98I; Ambrose and Norr, I993) (cf. Kupke, 20II). 


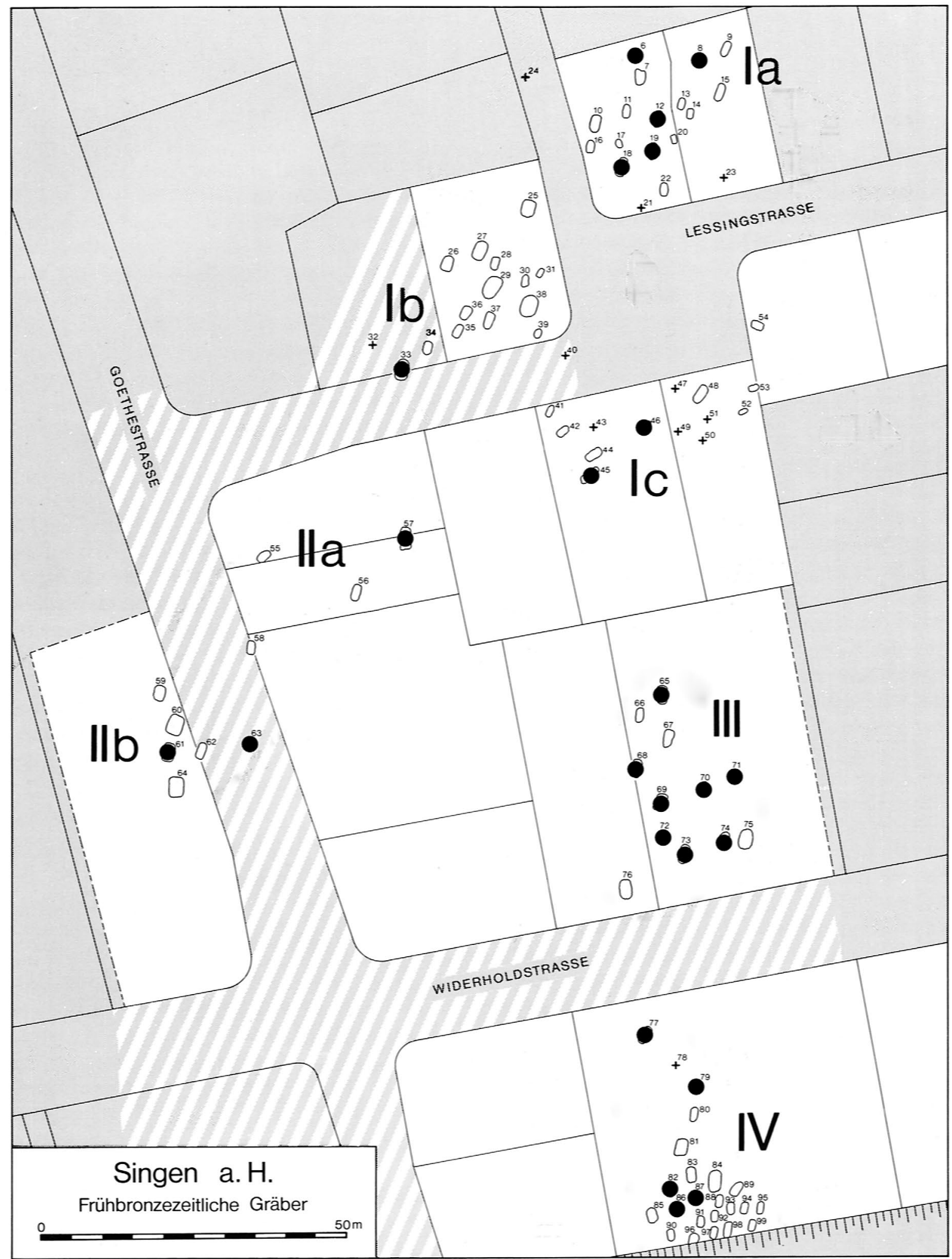

Fig. 4 | Singen, district of Constance, Baden-Württemberg, Germany. Distribution of individuals yielding samples (Map: from Krause, I988, p. 28 Fig. 6; mapping: Katharina Kupke) 


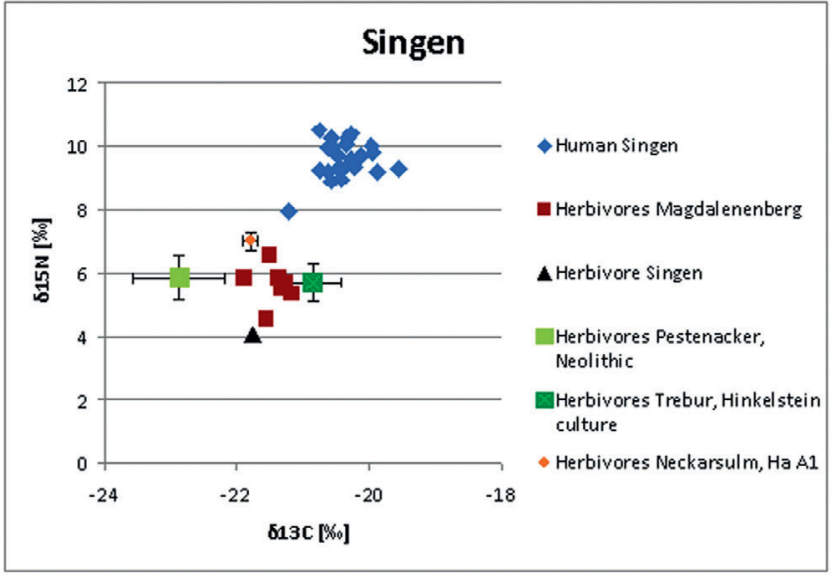

Fig. 5 | Singen, district of Constance, Baden-Württemberg, Germany. Data for carbon and nitrogen isotope analyses of the Singen individuals in comparison with isotope values for animals from other sites. (Graphic: Katharina Kupke)

The scatter of both the $\delta^{13} \mathrm{C}$ values and the $\delta^{15} \mathrm{~N}$ values for the Singen individuals is small. The range of $\delta^{{ }^{13} \mathrm{C}}$ values is between $-\mathrm{I} 9.6 \%$ and $-20.8 \%$, the $\delta^{{ }^{15} \mathrm{~N}}$ values range from $8.9 \%$ to $10.5 \%$ (children of the infans I age group were excluded, as their values could have been influenced by breastfeeding). The values suggest a terrestrial diet based on $\mathrm{C}_{3}$ plants and herbivorous animals. Dietary input from $\mathrm{C}_{4}$ plants ( $\delta^{{ }^{13}} \mathrm{C}$ values between $-9 \%$ and $-\mathrm{I} 6 \%$ ) can be excluded (Vogel, I980). This result is confirmed by archaeobotanical finds. The most important cereal species cultivated in the Early Bronze Age was spelt, followed by emmer, common wheat and barley (Frank, 2006). In addition to lentils and peas, gathered plants, such as blackberry, elderberry, wild strawberry, raspberry, hazelnuts, sloe and apple, were also consumed (Frank, 2006; Köninger, 2006; Körber-Grohne, I995). A starting point for the reconstruction of the meat component of the diet is provided by Layer A of the slightly younger settlement at BodmanSchachen I on Lake Constance. There, cattle, sheep, goat, pig and, to a lesser extent, horse and wild animals such as red deer, wild boar, roe deer, rabbit and birds are attested (Kokabi, I987, I990). In addition to providing meat, however, animals may have contributed products such as eggs, milk and other dairy produce to the human diet.

As is also the case for other sites in Germany (e.g., Asam et al., 2006), the $\delta^{13} \mathrm{C}$ values for the Singen cemetery do not show a canopy effect. A canopy effect would be manifested by more negative values (Ambrose and Norr, I993; Van der Merwe and Medina, I99I; Van Klinken et al., 2000). This result confirms data from pollen profiles in the surroundings of Singen and Lake Constance. Thus, we were able to ascertain that a clearance episode during which the dense mixed beech forest was thinned out occurred at the time of the Singen cemetery (Rösch, I990a, I990b). Areas now devoid of trees were used for agriculture (Frank, 2006).

Breastfeeding has an impact on the isotope ratios of children in the infant age group (under 6 years). Since young infants absorb their mother's protein through breast milk, their $\delta^{15} \mathrm{~N}$ values are about 3-4\% higher than those of the adult females in the population (Mays et al., 2002; Richards et al., 2002). Only the child from Grave 46 could be assigned to the infant age group. It has been anthropologically aged to between I. 5 and 6 years, but exhibits a very low $\delta^{15} \mathrm{~N}$ value of $7.9 \%$. There is thus no evidence for any influence through breast milk. Indeed, this child had very probably already been weaned and received an omnivorous diet with a focus on vegetarian food.

Furthermore, we investigated whether dietary differences existed among the morphologically defined age and sex groups and whether there was a relationship between the social index values and diet. No statistically significant results could be obtained with respect to relationships between the isotope 
Fig. 6 | Singen, district of Constance, Baden-Württemberg, Germany. Correlation between age groups and $\delta^{15} \mathrm{~N}$ values. Infans I were excluded due to the possible impact from breastfeeding (Graphic: Katharina Kupke)

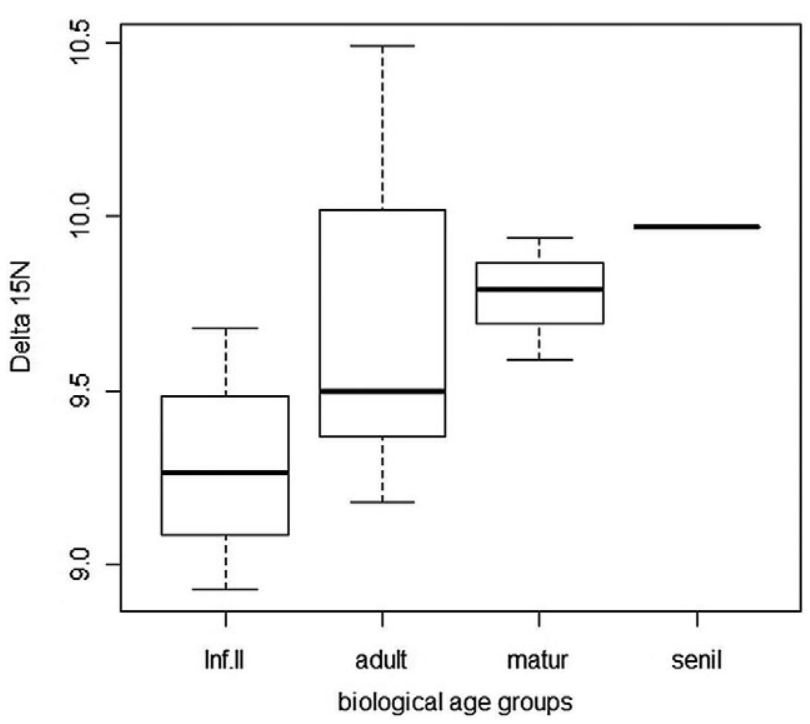

values for carbon and nitrogen and sex or the social index values, i.e., women and men consumed the same foods (protein) and there were no discernable dietary differences among individuals assigned different social index values. In order to identify possible statistically significant differences in diet among the different age groups, Spearman's rank correlation coefficient was applied and significance tested for. The relationship between age groups and $\delta^{15} \mathrm{~N}$ values is significant, i.e. the older the individuals were, the more meat they consumed $(\varrho=0.56$; $p$-value=0.04). Since this observation is based on only I4 individuals, the significance of this result must be seen as particularly marked. There is hence a certain justification for assuming that a positive correlation between age and the proportion of meat in the diet applies to the Singen cemetery as a whole (Fig. 6).

\section{Archaeological project}

\section{Research questions}

The prehistoric component project concentrates on the question of the socio-cultural integration of each single individual in the Singen or Magdalenenberg populations at the point of his or her burial. Thus the main question is to what degree were individuals who have 'foreign' characteristics in their grave good assemblage or their funerary rites actually integrated into the burial community? This approach resulted in a methodological shift away from an emphasis on detecting mobility, as archaeology is capable of recognising ideas and/or objects as foreign, but not really the individuals themselves. Instead, research here focuses on integration, which is manifested as an individual combination and admixture of grave inventories.

Methodologically, the integration analysis is the centrepiece of the prehistoric study. This analysis is inspired by a standardised psychometric personality test borrowed from Psychology (cf. Hossiep, 2007) and is designed to measure the culturally determined degree of integration of an individual within his or her burial community by considering foreign elements. 'Foreign' in this context means that a) the main area of distribution of a given trait lies outside the cemetery and the regional grouping to which it be- 
longs and/or b) the type in question is only rarely present. In practice, lists of questions are used to determine the chorological character of selected elements for each burial complex; in a further step, social groups are defined on the basis of multivariate statistics.

\section{Steps of analysis}

Again, at this point we can present only the first steps, since the project team is currently in the middle of testing the integration analysis with the first case study, having completed general preparations in the first year of the project.

In detail, the procedure will be as follows:

I. A list of the relevant finds and funerary rites for the cemetery will be drawn up.

2. The frequency of the selected elements in a) the cemetery and b) the surrounding regions will be identified. It is here that the discussion as to what can be classified as 'normal' or as 'foreign' begins.

3. The main areas of distribution of the selected finds and ritual elements will be identified and plotted on maps. These maps will form the basis for the definition of wider regions, which is required for the subsequent "questionnaire" stage, to allow the contact regions from which foreign elements were derived to be investigated.

4. A list of questions will be drawn up for use in the analysis and the corresponding values will be calculated.

5. Finally, we will attempt to define groups with different integration characteristics with the aid of correspondence and cluster analysis.

The Singen cemetery contains only inhumation graves, within which the dead were buried in a crouched position differentiated by gender (Fig. 8). Women were buried crouched on their right, head to the south; men, crouched on their left with head to the north (see Rieckhoff, I998). R. Krause (I988) defined seven types of grave structures, ranging from grave pits containing only stone wedges for a possible log coffin to stone cists. The Early Bronze Age grave good spectrum comprised essentially three types of pin (racket-headed pins [Ruderkopfnadeln], disc-headed pins [Scheibenkopfnadel] and disc-headed pins with a thin wire connecting the top with the neck [Typ Horkheim]), awls, triangular daggers with two to five rivets, spiral arm-rings, ingot torque (Ösenhalsring), a so-called diadem, bone rings and various pendants and beads, including one of the earliest faïence beads found in southern Germany (Krause, I988; Weiss, I998). The materials used comprise bone, three different bronze alloys with increasing tin content, silver, jet and a little pottery. Only the right-crouched inhumations (i.e. the women) contained racket-headed pins (Ruderkopfnadeln), neck-rings with turned ends and awls. Daggers occur mostly with left crouched inhumations (i.e., men), but in two cases they were recovered in graves archaeologically identified as those of women. All other grave goods are found with equal frequency for both sex groups or come from graves without bone preservation, i.e. where reconstruction of the the position and hence gender of the deceased is impossible and which therefore cannot be classified with certainty. Also, some grave goods occur only once. A third of the graves were unfurnished.

The most frequent grave goods are spiral arm-rings, daggers of the Straubing-Adlerberg type and racket-headed pins [Ruderkopfnadeln] (Fig. 7). At the infrequent end of the grave good list are a bone button, a lunula pendant, a diadem, two silver wire rings, a pair of ankle rings, several spiral coils, assorted beads and four daggers, perhaps from Early Bronze Age southern England or Brittany. At this stage, the discussion of where the boundary between rare and more frequent grave goods, between 'normal' and 
Fig. 7 | Singen, district of Constance, Germany. Frequency of types within the grave inventories (Graphic: Julia Koch)

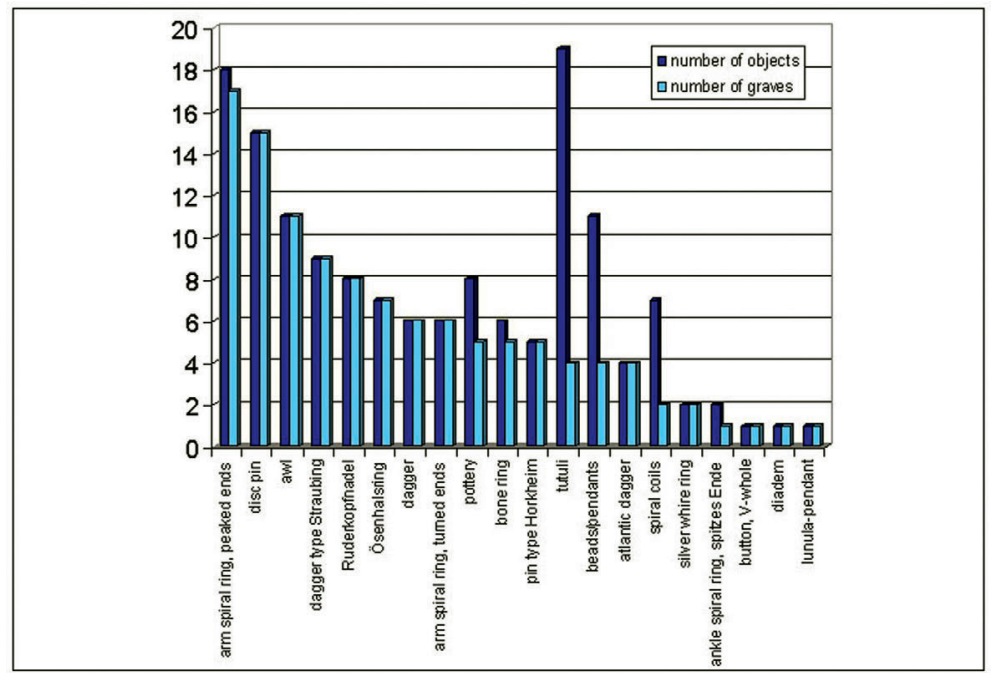

'possibly foreign', should be drawn has not yet been resolved. A record of the frequency of other elements of the funerary rite also exists. For example, certain grave goods occur relatively frequently, but show a divergent position in only a few graves. Figure 8 is a schematic representation showing all grave goods with known positions. As the majority of goods were found around the head, chest and arms, divergent examples such as tutuli or a bone ring on the back, a dagger at the hip or a pair of ankle rings are extremely conspicuous (see Rieckhoff, I998). Might these also represent 'foreign characteristics'? Thus frequency alone cannot be used as a straightforward detector of 'foreign individuals' but it is an analytical step necessary in order to sort the material and to organize the subsequent investigation more systematically.

Fig. 8 | Singen, district of Constance, Germany. Schematic representation of all artefacts with known position in the graves, including daggers, pins (racket-headed pins [Ruderkopfnadeln], disc-headed pins [Scheibenkopfnadel] and disc-headed pins with a thin wire connecting the top with the neck [Typ Horkheim]), spiral rings, tutuli, pendants and beads, neck rings with turned ends, bone rings und awls. Black symbol: known position; symbol with dotted line: known approximate position (Graphic: Julia Koch)
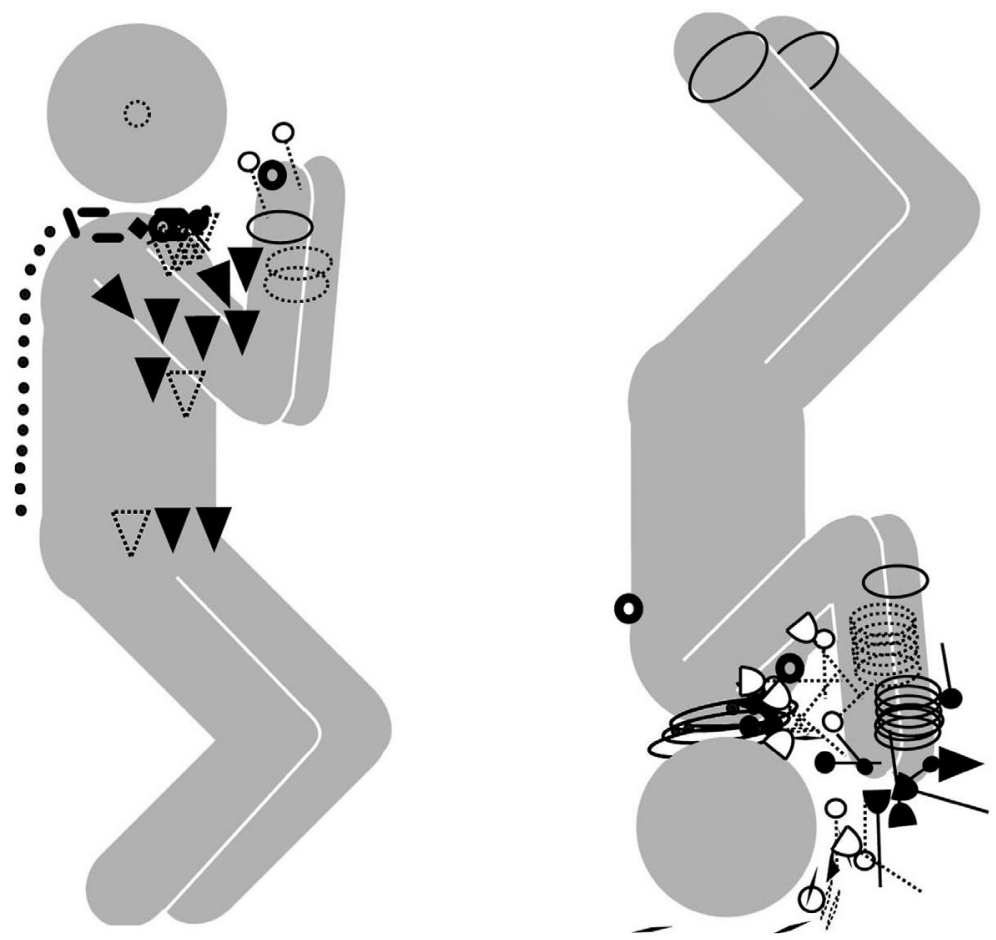
The next step consists of compiling the distributions of the individual elements of grave furnishings, the decorations on the pins and different aspects of the funerary rite, such as the position of goods, the position and orientation of the deceased and any structures in the grave. The map depicts three examples whose main areas of distribution lie in three different cardinal directions (Fig. 9). Four daggers point as far as Brittany or southern England (Krause, I988; Gerloff, I975), while the lunula pendant finds its most frequent parallels in the Alpine Valais (Krause, I988; Primas, I997) and diadems are mostly distributed along the Danube (Krause, I988; critically: Gallay, I99I).

Maps like these will serve as the basis for the general map of contact regions, which has yet to be completed. Currently a work in progress, the creation of that map entails the analysis of the distribution patterns and boundaries of the different artefacts and funerary rites. The collected maps of artefacts and other markers will be classified on the basis of the distribution patterns. Markers with a very widespread, regular multicultural distribution, such as awls, are less suited for the analysis of cultural contacts. Of greater interest are those markers associated with a more restricted regional distribution or with clear distribution centres and only few outliers. Focussing to Singen, we then have to find out where the oldest examples of each marker occur, if it is possible to identify them (cf. the discussion regarding the origin of the "Linienbandwinkel" decoration pattern [i.e. linear bands at right-angle]: Schwenzer, 2004).

The subsequent methodological steps, such as drawing up the list of questions (including questions such as "Where is the main distribution area (i.e. contact region) for the position the jewellery, weapons etc. take in the grave?"), calculating the integration analysis values and then carrying out the correspondence and cluster analyses will keep the project team busy in the coming weeks and months.

Finally, the results will be compared with the available anthropological data, with the results of published studies such as the social index analysis carried out by Sylvia Sprenger (I993, I995), and, of course, with the results of the natural sience partner project. In the moment stage of work [2010], we are not yet in a position to illustrate precisely what impact the integration of isotopic data will have on the overall analysis, and have focussed instead on how the archaeological data sets for the comparison will be developed.

\section{Outlook}

After comparing the data from the two projects, the aim for the final year, 20II, is to interpret the different integration clusters and to develop a synthesis, encompassing models for the interconnections between mobility and cultural development. The reconstruction of social life courses involves not only the basic archaeological and anthropological data on age, sex, gender, social status and dating, but also data on diet and mobility at different ages and the cultural integration into a burial community at the end of the individual's life. Returning to the basic question the project seeks to address, the role of individual mobility and integration in the development of prehistoric sedentary societies, it would be important to show whether the differences between social groups are due to mobility or to other factors, such as the probably age-determined difference in diet at Singen. This project cluster synthesis combines the results from both component projects into an overall picture of individual geographic mobility on the one hand, and, on the other, the cultural integration of nonlocals and/or semi-integrated persons. This will enable the reconstruction of a mobility spectrum for the cases under study. The aim is to utilize 


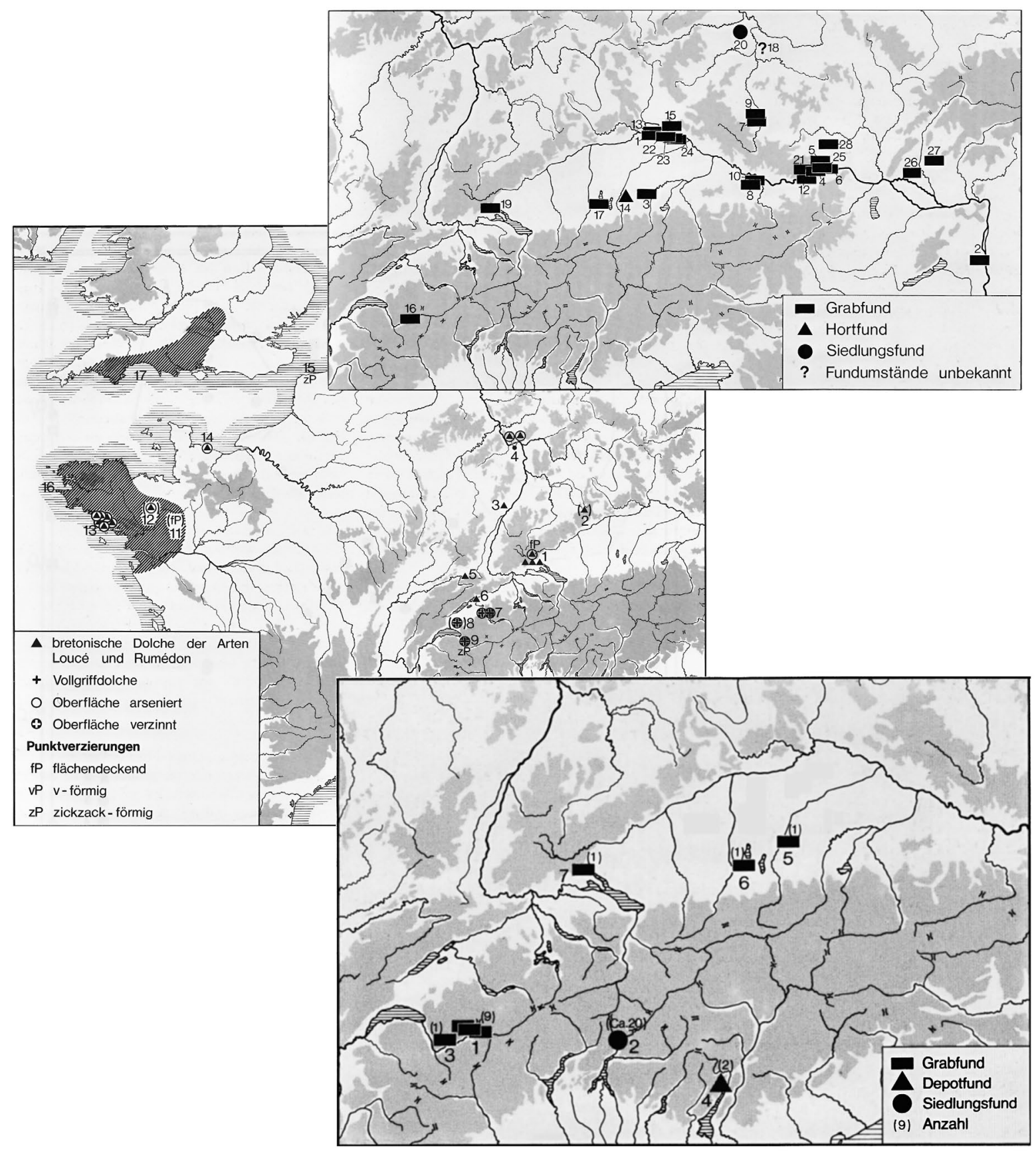

Fig. 9 | Three distribution maps of EBA artefact types found at the cemetery of Singen (from Krause I988, p. 59 Fig. 2I; p. 89 Fig. 45; p. 92 Fig. 47) 
these reconstructed life courses to investigate the postulated relationship between individual mobility and the introduction of new metallurgical knowledge connected to fundamental innovations in Bronze Age and Iron Age societies over a short time scale.

\section{Acknowledgements}

This paper is one of the publications of the research project, publicly funded in 2008-II by the Federal Ministry of Education and Research, Germany, with the support code oiUAo8II. The authors are responsible to the content of this paper.

We thank Claudia Hofmann, Oxford, for translation. Sabine Rieckhoff and Michael Richards are thanked for supervision of the project and Olaf Nehlich for introduction in isotope-analysis. We thank for samples making available Joachim Wahl, Konstanz, Jürgen Hald, Kreisarchäologie Konstanz, and Ralph Stephan, Hegau-Museum Singen.

\section{References}

Alt, K.W., 2004. Dimensionen von Alter und Geschlecht in der Ontogenese des Menschen - Archäologische Implikationen. Ethnographisch-Archäologische Zeitschrift 46 (2-3), I53-164.

Ambrose, S.H., I990. Preparation and characterization of bone and tooth collagen for isotopic analysis. Journal of Archaeological Science I7, 43I-45I.

Ambrose, S.H., Norr, L., I993. Experimental evidence for the relationship of the carbon isotope rations of whole diet and dietary protein to those of bone collagen and carbonate, in: Lambert, J.B., Grupe, G. (Eds.), Prehistoric Human Bone: Archaeology at the Molecular Level. Springer-Verlag, New York, pp. I-39.

Asam, T., Grupe, G., Peters J., 2006. Menschliche Subsistenzstrategien im Neolithikum: Eine Isotopenanalyse bayrischer Skelettfunde. Anthropologischer Anzeiger $64, \mathrm{I}-23$.

Berry, J.W., I990. Psychology of acculturation: Understanding moving between cultures, in: Brislin, R.W. (Ed.), Applied Cross-Cultural Psychology: Cross-cultural Research and Methodology Series I4. Sage, Newbury Park, pp. 232-253.

Bol, R., Marsh J., Heaton, T.H., 2007. Multiple stable isotope $\left({ }^{18} \mathrm{O},{ }^{13} \mathrm{C},{ }^{15} \mathrm{~N}\right.$ and $\left.34 \mathrm{~S}\right)$ analysis of human hair to identify the recent migrants in a rural community in SW England. Rapid Communications in Mass Spectrometry 2I, 295I-2954.

Brestrich, W., I998. Die mittel- und spätbronzezeitlichen Grabfunde auf der Nordstadtterrasse von Singen am Hohentwiel. Forschungen und Berichte zur Vorund Frühgeschichte in Baden-Württemberg 67. Theiss, Stuttgart.
Brown, T.A., Nelson, D.E., Vogel, J.S., Southon, J.R., I988. Improved collagen extraction by modified Longin method. Radiocarbon 30 (2), I7I-I77.

Buchardt, B., Bunch, V., Helin, P., 2007. Fingernails and diet: Stable isotope signatures of a marine hunting community from modern Uummannaq, North Greenland. Chemical Geology 244, 316-329.

DeNiro, M.J., I985. Postmortem preservation and alteration of vivo bone collagen isotope ratios in relation to palaeodietary reconstruction. Nature 3I7, 806-809.

DeNiro, J.M., Epstein, S., I978. Influence of diet on the distribution of carbon isotopes in animals. Geochimica et Cosmochimica 42, 495-506.

DeNiro, M.J., Epstein, S., I98I, Influence of diet on the distribution of nitrogen isotopes in animals. Geochimica et Cosmochimica Acta 45, 34I-35I.

Dürrwächter, C., Craig, O., Taylor, G., Collins, M., Burger, J., Alt, K.W., 2003. Rekonstruktion der Ernährungsweise in den mittel- und frühneolithischen Bevölkerungen von Trebur/Hessen und Herxheim/Pfalz anhand der Analyse stabiler Isotope. Bulletin Societé Suisse d'Anthropologie 9, I-I6.

Frank, K.S., 2006. Botanische Makroreste aus Tauchgrabungen in den frühbronzezeitlichen Seeufersiedlungen Bodman-Schachen I am nordwestlichen Bodensee unter besonderer Berücksichtigung der Morphologie und Anatomie der Wildpflanzenfunde. Aussagemöglichkeiten zu Nutzpflanzen, Vegetationsverhältnissen und zur Lage des Siedlungsareals, in: Köninger, J. (Ed.), Die frühbronzezeitliche Ufersiedlung von Bodman-Schachen I - Befunde und Funde 
aus den Tauchsonden I982-I984 und I986. Siedlungsarchäologie im Alpenvorland VIII. Forschungen und Berichte zur Vor- und Frühgeschichte in Baden-Württemberg 85. Theiss, Stuttgart, pp. 43I-566.

Gallay, G., I977. Die Körpergräber aus dem Magdalenenberg bei Villingen, in: Spindler, K., Der Magdalenenberg. Der hallstattzeitliche Fürstengrabhügel bei Villingen im Schwarzwald 5. Neckar-Verlag, Villingen, pp. 79-II8.

Gallay, G., I99I. Book review "Rüder Krause, Die endneolithischen und frühbronzezeitlichen Grabfunde auf der Nordstadtterrasse von Singen am Hohentwiel. Forschungen und Berichte zur Vor- und Frühgeschichte Baden-Würtemberg 32. Theiss, Stuttgart I988". Germania 69, 204-207.

Gerloff, S., I975. The Early Bronze Age daggers in Great Britain and a reconsideration of the Wessex Culture. Prähistorische Bronzefunde VI, 2. C.H. Beck, Munich.

Gilchrist, R., I999. Gender and Archaeology: Contesting the Past. Routledge, London.

Gilchrist,R., 2000. Archaeological biographies: Realizing human lifecycles, -courses and -histories. World Archaeology 31, 325-328.

Hossiep, R., 2007. Messung von Persönlichkeitsmerkmalen, in: Schuler, H., Sonntag, K. (Eds.), Handbuch der Arbeits- und Organisationspsychologie. Hogrefe, Göttingen, pp. 450-458.

Jay, M., Richards, M.P., 2006. Diet in the Iron Age cemetery population at Wetwang Slack, East Yorkshire, UK: Carbon and nitrogen stable isotope evidence. Journal of Archaeological Science 33, 653-662.

Koch, J.K., 20IO. Mobile Individuen in sesshaften Gesellschaften der Metallzeiten Mitteleuropas. Anmerkungen zur Rekonstruktion prähistorischer Lebensläufe, in: Meller, H., Alt, K. (Eds.), Anthropologie, Isotopie und DNA - biographische Annäherung an namenlose vorgeschichtliche Skelette? 2. Mitteldeutscher Archäologentag Halle an der Saale 2009. Tagungen des Landesmuseums für Vorgeschichte 3 . Landesmuseum für Vorgeschichte, Halle, pp. 95-100.

Kokabi, M., I987. Die Tierknochenfunde aus den neolithischen Ufersiedlungen am Bodensee - Versuch einer Rekonstruktion der einstigen Wirtschafts- und Umweltverhältnisse mit der Untersuchungsmethode der Osteologie. Archäologische Nachrichten Baden 38-39, 6I-66.

Kokabi, M., I990. Ergebnisse der osteologischen Untersuchungen an den Knochenfunden von Hornstaad im Vergleich zu anderen Feuchtbodenfundkomplexen Südwestdeutschlands. Bericht der Römisch-Germanischen Kommission 7I, I45-I60.
Köninger, J., 2006. Die frühbronzezeitliche Ufersiedlung von Bodman-Schachen I - Befunde und Funde aus den Tauchsonden I982-I984 und I986. Siedlungsarchäologie im Alpenvorland VIII. Forschungen u. Berichte zur Vor- und Frühgeschichte in Baden-Württemberg 85 . Theiss, Stuttgart.

Körber-Grohne, U., I995. Nutzpflanzen in Deutschland. Von der Vorgeschichte bis heute. Theiss, Stuttgart.

Krause, R., I988. Die endneolithischen und frühbronzezeitlichen Grabfunde auf der Nordstadtterrasse von Singen am Hohentwiel. Forschungen und Berichte zur Vor- und Frühgeschichte Baden-Würtemberg 32. Theiss, Stuttgart.

Krause, R., 2002. Sozialstrukturen und Hierachien Überlegungen zur frühbronzezitlichen Metallurgiekette im süddeutschen Alpenvorland, in: J. Müller (Ed.), Vom Endneolithikum zur Frühbronzezeit. Muster sozialen Wandels? Tagung Bamberg 200I. Universitätsforschungen zur Prähistorischen Archäologie 90. Habelt, Bonn, pp. 45-59.

Krause, R., 2009. Bronze Age copper production in the Alps: Organisation and social hierarchies in mining communities, in: Kienlin, T.L., Roberts, B.W. (Eds.), Metals and Societies. Studies in Honour of Barabara S. Ottoway. Universitätsforschungen zur Prähistorischen Archäologie I69. Habelt, Bonn, pp. 47-66.

Kupke, K., 20II. Ernährungsrekonstruktion mittels Kohlenstoff- und Stickstoffisotopen aus dem frühbronzezeitlichen Gräberfeld von Singen, Kr. Konstanz und den früheisenzeitlichen Gräbern im Magdalenenberg bei Villingen, Schwarzwald-Baar-Kreis. Master thesis, Leipzig University.

Longin, R., I97I. New method of collagen extraction for radiocarbon dating. Nature 230, 24I-242.

Mays, S.A., Richards, M.P., Fuller, B.T., 2002. Bone stable isotope evidence for infant feeding in Mediaeval England. Antiquity 76, 654-656.

Müldner, G., Richards, M.P., 2005. Fast or feast: reconstructing diet in later medieval England by stable isotope analysis. Journal of Archaeological Science 32, 39-48.

Nehlich, O., Richards, M.P., 2009. Establishing collagen quality criteria for sulphur isotope analysis of archaeological bone collagen. Archaeological and Anthropological Sciences I, 59-75.

Nehlich, O., Wahl, J., 20ıо. Binnengewässer - eine unterschätzte Nahrungsressource - Stabile Kohlenstoff-, Stickstoff- und Schwefelisotope aus dem Kollagen menschlicher und tierischer Knochenreste aus der urnenfelderzeitlichen Nekropole von Neckarsulm. Fundberichte aus Baden-Württemberg 3I, 97-II3.

Oelze, V., Nehlich, O., Richards, M.P. (submitted manuscript/revised). 'There's no place like home' - 
No isotopic evidence for mobility at the Early Bronze Age cemetery of Singen, Germany. Archaeometry.

Primas, M., I997. Der frühbronzezeitliche Depotfund von Arbedo-Castione (Kt. Tessin, Schweiz), in: Becker, C. et al. (Eds.), Xøóvos. Beiträge zur Prähistorischen Archäologie zwischen Nord- und Südosteuropa. Festschrift B. Hänsel. Internationale Archäologie - Studia honoraria I. Leidorf, Espelkamp, pp. 287-296.

Richards, M.P., in press. Stable Isotopes in Archaeology. Cambridge Manuals in Archaeology. Cambridge University Press.

Richards, M.P., Hedges, R.E.M., I999. Stable isotope evidence for similarities in the types of marine foods used by late Mesolithic humans at sites along the Atlantic Coast of Europe. Journal of Archaeological Science 26, 7I7-722.

Richards, M.P., Fuller, B.T., Hedges, R.E.M., 200I. Sulphur isotopic variation in ancient bone collagen from Europe: implications for human palaeodiet, residence mobility, and modern pollutant studies. Earth and Planetary Science Letters I9I, I85-I9O.

Richards, M.P., Mays, S., Fuller, B.T., 2002. Stable carbon and nitrogen isotope values of bone and teeth reflect weaning age at the Medieval Wharram Percy Site, Yorkshire, UK. American Journal of Physical Anthropology II9, 205-210.

Rieckhoff, S., I998. Gräber der Bronzezeit, in: Das Geheimnis des Bernstein-Colliers. Ingolstadt, pp. 73-84.

Rösch, M., I990a. Vegetationsgeschichtliche Untersuchungen im Durchenbergried, in: Siedlungsarchäologie im Alpenvorland II. Forschungen und Berichte zur Vor- und Frühgeschichte in Baden-Württemberg 37. Theiss, Stuttgart, pp. 9-64.

Rösch, M., I99ob. Veränderung von Wirtschaft und Umwelt während Neolithikum und Bronzezeit am Bodensee. Bericht der Römisch-Germanischen Kommission 7I (I), I6I-I86.

Schmid-Sikimić, B., 2002. Mesocco Coop (GR). Eisenzeitlicher Bestattungsplatz im Brennpunkt zwischen Nord und Süd. Universitätsforschungen zur Prähistorischen Archäologie 88. Habelt, Bonn.

Schwenzer, St., 2004. Frühbronzezeitliche Vollgriffdolche. Kataloge Vor- und Frühgeschichtlicher Altertümer 36. Verlag RGZM, Mainz.

Sofaer Derevenski, J., I997. Engendering Children, Engendering Archaeology, in: Moore, J., Scott, E. (Eds.), Invisible People and Processes: Writing Gender and Childhood into European Archaeology. London, Leicester University Press, pp.I92-202.

Spindler, K., I97I-80. Der Magdalenenberg. Der hallstattzeitliche Fürstengrabhügel bei Villingen im Schwarzwald I-6. Neckar-Verlag, Villingen.
Spindler, K., I999. Der Magdalenenberg bei Villingen. Ein Fürstengrabhügel des 7. vorchristlichen Jahrhunderts. Führer archäologische Denkmäler Baden-Württemberg $5,2^{\text {nd }}$ ed. Theiss, Stuttgart.

Spindler, K., 2004. Der Magdalenenberg bei Villingen im Schwarzwald: Bilanz nach dreißig Jahren, in: B. Hänsel (Ed.), Parerga Praehistorica. Jubiläumsschrift zur Prähistorischen Archäologie. I5 Jahre UPA. Universitätsforschungen zur Prähistorischen Archäologie roo. Habelt, Bonn, pp. I35-I59.

Sprenger, S., I993. Untersuchungen zu Sozialstrukturen und Geschlechterrollen am frühbronzezeitlichen Gräberfeld von Singen. MA thesis, University Freiburg.

Sprenger, S., I995. Untersuchungen zu Sozialstrukturen und Geschlechterrollen am frühbronzezeitlichen Gräberfeld von Singen. Ethnographisch-Archäologische Zeitschrift 36, I9I-200.

Steuer, H., 200I. Mobilität, in: Reallexikon Germanischer Altertumskunde Vol. 20, $2^{\text {nd }}$ ed. de Gruyter, Berlin, pp. II8-I23.

Van der Merwe, J.N., Medina, E., I99I. The canopy effect, carbon isotope ratios and foodwebs in Amazonia. Journal of Archaeological Science I8, 249-259.

Van Klinken, G.J., I999. Bone collagen quality indicators for paleodietary and radiocarbon measurements. Journal of Archaeological Science 26, 687-695.

Van Klinken, G.J., Richards, M.P., Hedges, R.E.M., 2000. An overview of causes for stable isotopic variations in past European human populations: Environmental, ecophysiological, and cultural effects, in: Ambrose, S.H., Katzenberg, M.A. (Eds.), Biochemical Approaches to Paleodietary Analysis. Advances in Archaeological and Museum Science. New York, pp. 39-63.

Vika, E., 2009. Strangers in the grave? Investigating local provenance in a Greek Bronze Age mass burial using $834 \mathrm{~S}$ analysis. Journal of Archaeological Science 36 , 2024-2028.

Vogel, J.C., I980. Fractionation of the carbon isotopes during photosynthesis, in: Vogel, J.C. (Ed.), Sitzberichte der Heidelberger Akademie der Wissenschaften 3, Io9-I35.

Wahl, J., Zäuner, St., 2ого. Zur demographischen Struktur der Bestattungen im späthallstattzeitlichen Grabhügel vom Magdalenenberg (unpublished manuscript, Dep. of Archaeological Heritage Baden-Württemberg).

Weiss, R.-M., I998. Ein Grabfund der frühen Bronzezeit aus Mangolding, Lkr. Regensburg. Ein Beitrag zum frühesten Glas in Mitteleuropa. Beiträge zur Archäologie in der Oberpfalz 2, 225-240. 